\title{
COMBINATION OF HOME CARE PHARMACY APPROACH AND NURSE'S HEALTH ACTION PROCESS APPROACH ON SELF CARE MANAGEMENT AND SELF EFFICACY IN ELDERLY WITH HYPERTENSION
}

\author{
Linda Juwita $^{1 *}$, Ninda Ayu Prabasari P. ${ }^{2}$, Restry Sinansari ${ }^{3}$ \\ 1,2,3 Widya Mandala Catholic University Surabaya \\ Email*: lindajuwita@ukwms.ac.id
}

\begin{abstract}
Introduction: There are still many hypertensive patients with uncontrolled hypertension and experiencing barriers to self-care. This study attempts to increase motivation and intention in self-care management and selfefficacy through the implementation combination of home pharmacy care approach and Health Action Process Approach (HAPA). This study aimed to know the combination of the Home Care Pharmacy Approach and Nurse's HAPA on self-care management and self-efficacy in the elderly with hypertension. Methods: It was a pre-experimental study that used one group pretest post-test design approach with the population, 60 people. Inclusion criteria were respondents with average blood pressure $\geq 140 / 90 \mathrm{mmHg}$ for two measurements. The sampling used a purposive sampling technique. The independent variable was the HAPA and Home Care Pharmacy. The dependent variable is self-care management and self-efficacy. Study instruments are questionnaire self-efficacy, self-care management, standard operating procedures, and HAPA Home Care Pharmacy. Data were analyzed by using paired t-test and Wilcoxon Sign Rank Test with significance paired $\alpha \leq$ 0.05. Results: Statistical paired t-test showed there was an increase in self-care management $(p=0.006)$. Statistical Wilcoxon Sign Rank Test showed there was no influence on the home pharmacy care approach and HAPA on self-efficacy $(p=0.753)$. Conclusions: It could be concluded that the implementation of collaboration in-home pharmacy care approach and HAPA improves self-care management. However, these interventions do not affect increasing self-efficacy. The excellent collaboration between healthcare providers will help patients maintain good health during treatment.
\end{abstract}

Keywords: health action process approach (hapa); home pharmacy care; hypertensive; self-care management; self-efficacy

\section{INTRODUCTION}

Hypertension, also known as high or raised blood pressure, is a condition in which the blood vessels have persistently raised pressure. Hypertension is diagnosed if, when it is measured on two different days, the systolic blood pressure readings on both days is $\geq 140 \mathrm{mmHg}$ and the diastolic blood pressure readings on both days is $\geq 90 \mathrm{mmHg}$. Uncontrolled hypertension can cause severe damage to the heart, such as angina, Heart attack, Heart failure, irregular heartbeat, which can lead to sudden death, stroke, and kidney damage, leading to kidney failure(WHO, 2019). With the handling of hypertension and its complex special treatment, long term treatment can be done to treat the contradiction from the patients (Triyanto, 2014). There are still many hypertensive patients who are not obedient in performing self-care properly(Baynouna et al., 2014).
Self-care is an activity to shape the independence of individuals in order to maintain their health (Orem, 2001). Selfcare management (self-care management), namely changing the physical signs, emotional signs, and evolving to determine what is needed in responding to the workings of those signs and changes (Riegal et al., 2010). The cause of uncontrolled hypertension patients and overcoming obstacles in performing self-care due to lack of knowledge, the increase of family support, did not affect the beliefs of the patients themselves (Findlow and Seymour, 2012). Older people with hypertension increase the difficulty of controlling blood pressure that will worsen their health (Nuraini, 2015).

WHO 2015 data shows that around 1.13 billion people suffer from hypertension. The number of people with hypertension in the world continues to increase every year. It is estimated that in 
2025 there will be 1.5 billion people suffered from hypertension. It is also estimated that every year there are 9.4 million people die from hypertension and complications (WHO, 2019). Preliminary survey data obtained from the Posyandu Lansia Sekar Arum, as many as $77 \%$ had above-normal blood pressure.

Older people with hypertension have difficulty doing self-care themselves that can worsen their health (Orem, 2001). There is a very significant positive effect between self-management and blood pressure (systolic and diastolic) (Lestari et al., 2018). A person who has hypertension and does not get regular treatment and control regularly will bring patients into severe cases such as the occurrence of heart disease, congestive heart failure, stroke, vision problems, kidney disease, and even death (Prabandari, 2014).

Hypertension is a disease that can be controlled with self-care management. The excellent behavior can maintain and support by the nurse's Health Action Process Approach (HAPA)(Han et al., 2015). It will keep the self-care management that patients have been formed (Kusnanto, Kurnia and Prasetia, 2015). A doctor or health worker must be able to motivate patients and families always to try to implement the preventive efforts (Rilantono, 2015). Hypertension treatment in a non-pharmacological way is done with a healthy lifestyle such as weight control, stress control, reduction of salt intake, low cholesterol, not smoking, and not consuming alcohol (Utami, 2017). Someone who understands about hypertension, its various causes and how to manage it will take the best possible action so that the disease will not continue (Setiawan, 2008). Home care services are considered to provide satisfactory to the elderly (Kouta, Kaite and Papadopoulos, 2015). The distributions of home care with counseling reportedly provide a better knowledge for the patients regarding the illness and can improve the quality of life of patients (Suryani et al., 2012)
On the other opinion, HAPA is the concept of an approach to patients who believe that to change a person's behavior can be done by increasing the intention through the motivational phase to alter an intention into action. Self-efficacy has an important role in formulating intentions (Schwarzer et al., 2003). HAPA has superiority compared to the other theories, in addition to explaining how the process of increasing motivation for the forming of intentions, HAPA explains how to maintain health behaviors that have been formed (Kusnanto, Kurnia and Prasetia, 2015). Based on the description above, researchers are interested in examining the effectiveness of collaborative approaches to Home Pharmacy Care and Health Action Process Approach (HAPA) by nurses on self-care management and self-efficacy in elderly with hypertension.

\section{METHODS}

This research is an experimental research type with a pre-experimental design that is the one group pretest-posttest design. The populations in this study are all the elderly in the one of Posyandu in Surabaya with amount 60 persons. The sample in this study is elderly with hypertension (both essential and secondary). The inclusion criteria were elderly with average systolic blood pressure $\geq 140$ $\mathrm{mmHg}$ and diastole $\geq 90 \mathrm{mmHg}$ during two examinations (JNC, 2003). The sample collection technique used in this study is purposive sampling. The numbers of samples in this study are 23 respondents.

The research did after the approval letter from respondents. The questioner distributed and filled by respondents before interventions combination of the home pharmacy care intervention methods and nurses HAPA approaches given. The visit conducted once a week for two weeks by the pharmacist and the nurse in the respondent's home. A visit by the pharmacist provides information regarding hypertension, pharmacological especially his patient medication and non- 
pharmacological treatment of hypertension, such as lifestyle, diet, and activities. Then after that, the nurse applies the HAPA method by providing motivation always to take medication and routine control and forming the respondent's intentions to follow diet and do good exercise. Standard Operating Procedures (SOP) are created by researchers as a reference for facilitators to carry out interventions. Self-care management questionnaire using a questionnaire developed and modified by Measuring Blood Pressure Knowledge and Self Care Behaviors of African American Peters and Templin, the questionnaire was modified and tested for validity by Prasetyo. The questioner still relevant and can be used to gain the aim of this research. The research has ten questionnaires with the maximum score 70 and the minimum score
10. The self-efficacy questionnaire uses a general perceived self-efficacy scale questionnaire from Scholz, Gutierrez, Sud, and Schwarzer (Prasetyo, 2012). The selfefficacy questioner has ten questions with a minimum score of 10 and the maximum score of 30. Both self-care management scores and self-efficacy scores will be divided into two groups are less and good. Analysis data used a paired t-test for selfcare management and Wilcoxon signedrank test used for self-efficacy.

Ethical considerations used in this research. This research got ethical clearance with the number 1276-KEPK from faculty of medicines Widya Mandala Catholic University. The other ethical consideration was used informed consent, anonymity, confidentiality, freedom, justice, and nonmaleficence.

\section{RESULTS}

Table 1. The Characteristics of Respondents' Demography $(n=23)$

\section{Characteristics}

\section{Frequency}

Percentage (\%)

1. Age
a. $46-55$
1
b. $56-65$
c. $>65$

2. Gender
a. Female
b. Male

3. Marital status
a. Married
b. Unmarried
c. Widower

4. Last education
a. No school
b. Elementary school
c. Junior High School
d. High School
e. College

5. Job

$\begin{array}{lll}\text { a. Private work } & 4 & 17.4 \\ \text { b. Entrepreneur } & 3 & 13 \\ \text { c. Civil Servant } & 1 & 4.3 \\ \text { d. Does not work } & 15 & 65.3\end{array}$




\section{$\begin{array}{lll}\text { Characteristics } & \text { Frequency } & \text { Percentage (\%) }\end{array}$}
a. Alone
1
b. Children
39.2
c. Spouse
34.8
d. Big family
21.7

6. Duration of suffering from hypertension
a. Forget
12
52.2
b. $>7$ years
8
34.8
c. $<7$ years
3
13

7.Drugs consumption
a. Yes and routine
8
34.8
b. No, and not a routine
15
65.2

The research showed the age of respondents namely: respondents aged in the middle-aged range (56-65 years) is $(52.2 \%)$, the majority of sex is female $(78.3 \%)$, the majority of marital status is married $(52.2 \%)$, the majority of last education is elementary and high school education (respectively $26.1 \%$ ), the majority of respondents are not working $(65.3 \%)$, the majority of respondents living together with children (39.2\%), the majority of old respondents suffer from hypertension have no idea of it $(52.2 \%)$, and the majority of respondents do not take drugs and do not routinely drink drugs $(65.2 \%)$.

Table 2. Pre Post Observation Result Self Care Management

\begin{tabular}{ccccc}
\hline Score(\%) & \multicolumn{2}{c}{ Pretest } & \multicolumn{3}{c}{ Posttest } \\
\cline { 2 - 5 } & $\mathbf{n}$ & \% & n & $\%$ \\
$<49$ & 20 & 87 & 14 & 60.9 \\
$\geq 49$ & 3 & 13 & 9 & 39.1 \\
\hline
\end{tabular}

Table 3. Self Care Management Test

\begin{tabular}{|c|c|c|c|c|c|c|c|c|}
\hline \multicolumn{6}{|c|}{ Paired Differences } & \multirow{2}{*}{\multicolumn{2}{|c|}{ t $\quad$ df }} & \multirow{2}{*}{$\begin{array}{l}\text { Sig. (2- } \\
\text { tailed) }\end{array}$} \\
\hline $\begin{array}{l}\text { Pair } \\
\text { pre- } \\
\text { post }\end{array}$ & Mean & $\begin{array}{l}\text { Standard } \\
\text { Deviation }\end{array}$ & $\begin{array}{l}\text { Standard } \\
\text { error } \\
\text { mean }\end{array}$ & Lower & Upper & & & \\
\hline & -6.565 & 10.461 & 2.181 & -11.089 & -2.041 & -3.010 & 22 & 0.006 \\
\hline
\end{tabular}

Table 4. Pre And Post Self Efficacy Observation Result

\begin{tabular}{cccccc}
\hline Score & Pre & Post \\
& f & \% & f & \% \\
\hline$<24$ & 3 & 13 & 1 & 4.3 \\
$\geq 24$ & 20 & 87 & 22 & 95.7 \\
\hline
\end{tabular}


Table 5. Statistic Result Of Self Efficacy Test

\begin{tabular}{lr}
\hline \multicolumn{2}{c}{ Post - Pre } \\
\hline $\mathrm{Z}$ & $-.315^{\mathrm{a}}$ \\
Asymp. Sig. (2-tailed) & .753 \\
\hline
\end{tabular}

The results showed that the majority of pretest self-care management is $<49$ from 20 people $(87 \%)$. Different results were obtained from respondents where the majority of posttest self-care management values < 49 were 14 people $(60.9 \%)$, which means that the majority of respondents' selfcare management was excellent. The observation results show that most pretest self-efficacy values are $\geq 24$ in 20 people $(87 \%)$, while the majority of the posttest self-efficacy values are $\geq 24$ in 22 people $(95.7 \%)$. Paired t-test results with value ( $\mathrm{p}=$ 0.006), which means there is an effect from the implementation of the collaboration of Home Pharmacy Care and Health Action Process Approach (HAPA) by nurses on self-care management in elderly with hypertension. Wilcoxon test results were conducted on self-efficacy data because the data were not normally distributed, and $\mathrm{p}=$ 0.753 was obtained, which means that there was no effect on the collaboration of the Home Pharmacy Care and Health Action Process Approach (HAPA) approach by nurses on self-efficacy in elderly with hypertension.

\section{DISCUSSIONS}

\section{Self-Care Management}

The research finding showed there is an effect on the implementation of the collaborative approach of the Home Pharmacy Care and Health Action Process Approach (HAPA) by nurses on self-care management in the elderly with hypertension. Proper self-care management may be caused by several factors, namely value, knowledge, self-efficacy, and social support. However, the implementation of self-care management is supported by several factors while still focusing on the individual themself in managing himself
(Pakseresht et al., 2010). In self-care theory, Orem said that self-care is an activity to shape the independence of individuals to maintain health (Orem, 2001). This is in line with the research results in which the Home Pharmacy Care approach by pharmacists and the Health Action Process Approach (HAPA) by nurses can support self-care management in elderly respondents in the treatment of hypertension. The Home Pharmacy Care approach is carried out by emphasizing how the respondent must regularly take medication to maintain his hypertension, including a routine for a hospital visit. Thus the drug can be carried out smoothly supported by the Health Action Process Approach (HAPA) approach by nurses making respondents have confidence that the behavior carried out is genuinely beneficial for himself primarily in maintaining health through good hypertension care.HAPA has the goal to see how a person (individual) processes before acting in health, explaining what motivates someone to change and how the person takes preventative actions (Schwarzer, 2008). Strengthening of nurses about the need to maintain health through dietary arrangements, lifestyle, avoiding smoking and stress management is needed by respondents who have limited sources of information so that information and reinforcement on things owned by the respondents make respondents more confident to be able to do a better self-care for the hypertension he suffered.

\section{Self-Efficacy}

The Wilcoxon Statistical Test obtained p-value $=0.753$, which means that there is no effect of the collaboration of the Home Pharmacy Care and Health Action Process Approach (HAPA) approach by 
nurses on self-efficacy in the elderly with hypertension. According to the Directorate of Community Pharmacy and Clinical Development in 2008 explained that one of the benefits of home pharmacy care increases understanding in management. This indicates that with home care by pharmacists related to the management of hypertension treatment does not guarantee a change in one's belief towards the better understanding but helps respondents to understand about the management of hypertension treatment correctly so that if the respondent already has reasonable feelings, then the respondent's confidence will get better. This is indicated by a change in the value of the pretest, which shows that respondents with self-efficacy less than 3 people change to 1 person because of the Home Pharmacy Care and Health Action Process Approach (HAPA) approach. The HAPA approach is emphasized on the social behavior-cognitive model of health behavior, which shows that changes in health behavior are a process that consists of a motivational phase and a will phase (Schwarzer, 2008). This gives an understanding of whether the respondent already has good motivation and goodwill, then this HAPA will strengthen the motivation and will that the respondent has already have. The statistical test results that there is no effect of the application of Home Pharmacy Care and HAPA on respondents' self-efficacy, but in terms of value that there is an increase towards more where there were 20 people in the pre-test $(87 \%)$ with good HAPA behavior, and it increased to 22 people $(95.7 \%)$. It can be seen that although there is no significant effect, there has also been an increase in self-efficacy in the respondents. The hypertension patient has the right motivation to maintain health as a human being as data said all the hypertension patients the minimum suffered the disease three years. This condition will support as human look for information and the best way to keep and maintain health include anything about life with hypertension and medication also.

\section{CONCLUSIONS}

There is an impact from the implementation of the collaborative approach from The Home Pharmacy Care and HAPA by nurses on self-care management in the elderly with hypertension. There is no effect on selfefficacy in the elderly with hypertension. This result implies that the excellent collaboration between the healthcare provider will help patients maintain good health during treatment, and a support system must be given to the patient during control or follow the procedure. Further, researchers can conduct new research using a control group and increase the number of respondents on a larger scale.

\section{REFERENCES}

Baynouna, L. M. et al. (2014) 'Audit of healthy lifestyle behaviors among patients with diabetes and hypertension attending ambulatory health care services in the United Arab Emirates', SAGE JOURNAL, 21(4), pp. 44-51. doi: $10.1177 / 1757975914528248$.

Findlow, J. W. and Seymour, R. B. (2012) 'NIH Public Access', J Natl Med Assoc, 103(6), pp. 503-512.

Han, H. R. et al. (2015) 'NIH Public Access', J Cardiosvasc Nurs, 29(3), pp. 1-16. doi: 10.1097/JCN.0b013e3182a3fd46.Dev elopment.

JNC (2003) Prevention, Detection, Evaluation, and Treatment of High Blood Pressure.

Kouta, C., Kaite, C. P. and Papadopoulos, I. (2015) 'Evaluation of Home Care Nursing for Elderly People in Cyprus', 8(2), pp. 376-384.

Kusnanto, Kurnia, I. D. and Prasetia, D. I. (2015) 'Penerapan " Health Action Process Approach " Untuk Meningkatkan Kepatuhan Diet Penderita Dm Tipe 2 ( Implementation of " Health Action Process Approach " to Improve 
Dietary Adherence in, Jurnal Ners, 10(2), pp. 272-278.

Lestari, I. G. et al. (2018) 'Pengaruh Self Management Terhaap Tekanan', 02(01), pp. 7-18.

Nuraini, B. (2015) 'Risk factors of hypertension', 4, pp. 10-19.

Orem, D. E. (2001). N. C. of practice (6th E. ). 'Nursing: Concept of practice (6th Ed.). St. Louis: St. Louis.

Pakseresht, M. et al. (2010) 'Awareness of chronic disease diagnosis amongst family members is associated with healthy dietary knowledge but not behaviour amongst Inuit in Arctic Canada'. doi: 10.1111/j.1365277X.2010.01101.x.

Prabandari, I. (2014) 'Fakultas ilmu kesehatan universitas muhammadiyah surakarta 2014'.

Prasetyo, A. S. (2012) 'Fakultas ilmu keperawatan program magister ilmu keperawatan kekhususan keperawatan medikal bedah depok, juli 2012'.

Riegal, B. et al. (2010) 'NIH Public Access', J Cardiovasc Nurs, 24(6), pp. 485-497. doi: 10.1097/JCN.0b013e3181b4baa0.An.

Rilantono, L. L. (2015) Penyakit
Kardiovaskular (PKV) 5 Rahasia. Jakarta: Badan Penerbit FKUI.

Schwarzer, R. et al. (2003) 'On the Assessment and Analysis of Variables in the Health Action Process Approach : Conducting an Investigation', pp. 1-18.

Schwarzer, R. (2008) 'Modeling Health Behavior Change: How To Predict And Modify The Adoption And Maintenance Of Health Behaviors.', Applied Psychology: An International Review, 57(1), pp. 1-29.

Setiawan (2008) Care Your Self, Hipertensi. Jakarta: PENEBAR PLUS.

Suryani, K. H. et al. (2012) 'Pengaruh Konseling Obat dalam', jurnal farm udayana, 2(3), pp. 6-11.

Triyanto, E. (2014) Pelayanan Keperawatan bagi Penderita Hipertensi secara Terpadu. Yogyakarta.: Graha Ilmu.

Utami, R. D. (2017) 'Tingkat Kepatuhan Perawat', Tingkat Kepatuhan Perawat, pp. 13-40.

WHO (2019) Hypertension. Available at: https://www.who.int/news-room/factsheets/detail/hypertension. 